\title{
Eksplorasi berpikir kreatif melalui discovery learning Bruner
}

\author{
Mulin Nu'man \\ Universitas Islam Negeri Sunan Kalijaga Yogyakarta, Indonesia \\ Email: mulin.nu@uin-suka.ac.id
}

\begin{abstract}
Abstrak
Berpikir kreatif merupakan komponen penting dari pemikiran matematika tingkat lanjut. Komponen berpikir kreatif adalah berpikir lateral (menciptakan cara sendiri dan non rutin), berpikir divergen (menggunakan berbagai macam cara), dan berpikir konvergen-integratif (menggunakan pola pada situasi lain). Salah satu cara mengembangkan berpikir kreatif adalah pembelajaran dengan discovery learning model Bruner yaitu pembelajaran dengan tahap enactive, iconic, dan symbolic. Kegiatan pembelajaran dengan discovery learning Bruner pada materi sistem persamaan linier dua variabel (SPLDV) untuk mengeksplorasi berpikir kreatif adalah: 1) kegiatan pendahuluan: tujuan dan apersepsi, 2) kegiatan inti meliputi: tahap enactive, yaitu pemberian masalah contextual untuk diselesaikan dengan cara siswa sendiri untuk mengeksplorasi berpikir lateral, tahap iconic, yaitu menuliskan solusi dan presentasi untuk mengeksplorasi berpikir divergen, dan tahap symbolic, yaitu elaborasi hasil tahap sebelumnya untuk dibawa ke proses matematika berupa pemodelan dan metode eliminasi dan substitusi untuk mengeksplorasi berpikir lateral, berpikir divergen, dan berpikir konvergen integratif, dan 3) kegiatan penutup: umpan balik dan penyimpulan.
\end{abstract}

Kata Kunci: Berpikir Kreatif, Discovery Learning Bruner, Kecakapan Abad 21 


\section{Abstract}

Creative thinking is an essential component of advanced mathematical thinking. The components of creative thinking are lateral thinking (creating one's own and non-routine ways), divergent thinking (using a variety of ways), and convergent-integrative thinking (using patterns in other situations). One way to develop creative thinking is learning with Bruner's discovery learning model, namely learning with an enactive, iconic, and symbolic stage. Learning activities with Bruner's discovery learning on the material of the two-variable linear equation system (SPLDV) to explore creative thinking are: 1) preliminary activities: goals and perceptions, 2) core activities include: the enactive stage, which is giving contextual problems to be solved themselves of students to explore lateral thinking, the iconic stage, which is writing solutions and presentations to explore divergent thinking, and the symbolic stage, which is the elaboration of the results of the previous stages to be brought to the mathematical process in the form of modeling and elimination and substitution methods to explore lateral thinking, divergent thinking, and convergent thinking integrative, and 3) closing activities: feedback and conclusions.

Keywords: Creative Thinking, Discovery Learning Bruner, 21st Century Skills

\section{Latar Belakang}

Pada Abad 21 ini, dunia pendidikan dituntut untuk mampu mengintegrasikan antara kecakapan pengetahuan, keterampilan, dan sikap (Singh, 2019), serta penguasaan terhadap Teknologi Informasi dan Komunikasi (TIK). Kecakapan tersebut dapat dikembangkan melalui berbagai model kegiatan pembelajaran berbasis pada aktivitas yang sesuai dengan karakteristik kompetensi dan materi pembelajaran. Selain dari pada itu, kecakapan yang dibutuhkan dalam dunia pendidikan pada Abad 21 adalah keterampilan berpikir lebih tinggi (Higher Order Thinking Skills (HOTS) yang sangat diperlukan dalam mempersiapkan peserta didik dalam menghadapi tantangan global.

Kecakapan Abad 21 yang terintegrasi dalam Kecakapan Pengetahuan, Keterampilan dan sikap serta penguasaan TIK dapat dikembangkan melalui: (1) Kecakapan Berpikir Kritis dan Pemecahan Masalah (Critical Thinking and Problem Solving Skill; (2) Kecakapan Berkomunikasi (Communication Skills); (3) Kecakapan Kreatifitas dan Inovasi (Creativity and Innovation); dan (4) Kecakapan Kolaborasi (Collaboration). (NEA, 2012) menyatakan bahwa setiap siswa harus memiliki 
empat kemampuan pada abad 21 untuk dapat bersaing dalam era globalisasi yaitu komunikasi, kolaborasi, berpikir kritis, serta berpikir kreatif. Kemampuan berpikir kreatif menjadi salah satu kemampuan yang harus dimiliki siswa sehingga siswa bisa lebih fokus dalam pembelajaran termasuk pembelajaran matematika. Hal ini sejalan dengan salah satu tujuan pembelajaran matematika yang tercantum di dalam kurikulum 2013 yaitu mempersiapkan siswa Indonesia agar memiliki kemampuan hidup sebagai pribadi dan warga negara yang kreatif (Permendikbud, 2013).

Berpikir kreatif merupakan salah satu jenis berpikir yang mengarah pada pemerolehan wawasan baru, perspektif baru, pendekatan baru, atau cara baru dalam memahami sesuatu (McGregor, 2007). Melalui proses berpikir kreatif, siswa belajar dengan cara melihat suatu pemecahan masalah dari berbagai sudut pandang dan belajar bagaimana menemukan jawaban yang inovatif serta dapat menyelesaikan permasalahan (Putri, Munzir, \& Abidin, 2019). Berpikir kreatif merupakan hal penting dalam bidang sosial, sehingga dengan kemampuan berpikir kreatif manusia dapat meningkatkan kualitas hidupnya (Robinson, 2011). (Hendriana, Rohaeti, \& Sumarmo, 2017) menjelaskan bahwa berpikir kreatif matematis merupakan kemampuan matematis esensial yang perlu dikuasai dan dikembangkan oleh siswa. Pembelajaran di sekolah yang dilaksanakan oleh guru hendaknya mengarah kepada kreativitas yaitu dengan mengajak siswa untuk menemukan sendiri solusi dari berbagai sudut pandang.

Berpikir kreatif mengacu pada kemampuan untuk menghasilkan ide atau solusi baru dalam proses pemecahan masalah. Definisi ini dibangun di atas aspek kreativitas menjadi sembilan konstruksi: fluency (kelancaran), flexibility (fleksibilitas), novelty (kebaruan), synthesis (sintesis), analysis (analisis), reorganization/redefinition (reorganisasi/ redefinisi), complexity (kompleksitas), dan elaboration (elaborasi) (Guilford, 1967). Dalam (Hadar \& Tirosh, 2019) terdapat tiga proses berpikir kreatif yaitu berpikir lateral, berpikir divergen dan berpikir konvergen-integratif. De Bono dalam (Hadar \& Tirosh, 2019) menyatakan bahwa berpikir lateral adalah berpikir secara fleksibel melompat dari satu aspek ke aspek lain daripada hanya mengikuti jalur yang sudah ada sebelumnya. Berpikir lateral membutuhkan kemampuan untuk berpikir secara asosiatif, menggunakan perspektif yang berbeda dalam berpikir di luar kotak untuk menciptakan ide-ide baru. Berpikir divergen adalah aspek jawaban untuk pertanyaan tentang apa yang dilakukan individu ketika mereka berpikir kreatif (Hadar \& Tirosh, 2019). Dalam berpikir divergen, individu menghasilkan banyak solusi untuk masalah yang tidak memiliki jawaban benar atau salah. 
Deskripsi tentang pemikiran konvergen-integratif sebagai jawaban ketiga yang individu mengidentifikasi elemen-elemen kunci dari suatu masalah, mencari tahu bagaimana bagian-bagian tersebut saling bersesuaian (Hadar \& Tirosh, 2019). Berpikir konvergen-integratif melihat hubungan baru, menggabungkan ide-ide yang berbeda, menentukan pola, dan membentuk hubungan baru antara entitas yang sebelumnya berbeda. Dalam tulisan ini akan diambil tiga aspek yaitu berpikir lateral, berpikir divergen, dan berpikir konvergen integratif.

Meskipun penting, kemampuan berpikir kreatif siswa masih mengkhawatirkan (Putri et al., 2019; Rahayu, Akbar, \& Afrilianto, 2018). Permasalahan tersebut dapat terjadi karena selama ini kemampuan berpikir kreatif kurang diperhatikan dalam pembelajaran matematika (Putri et al., 2019) Guru terbiasa memberikan soal-soal yang hanya memiliki jawaban ataupun cara tunggal sehingga mengakibatkan siswa hanya dapat menyelesaikannya dengan cara yang telah dicontohkan oleh guru. Padahal masalah yang hanya memiliki cara atau jawaban tunggal tidak mendorong siswa untuk berpikir kreatif, melainkan hanya menerapkan algoritma yang sudah diketahui (Siswono, Rosyidi, Astuti, \& Kurniasari, 2012).

Mengembangkan kemampuan berpikir kreatif siswa dapat dilakukan oleh guru dengan pembelajaran yang melatih siswa untuk menemukannya (Dewi \& Aman, 2019). Salah satu strategi belajar dan mengajar melalui model discovery learning. Discovery learning berarti bahwa dalam pembelajaran, siswa perlu dilatih untuk menemukan konsep atau teori yang relevan dengan materi yang diajarkan (Bruner, 2018; Takaya, 2015). Belajar dengan penemuan selalu melibatkan siswa untuk menemukan solusi dari masalah yang mereka pelajari dan pengalaman yang mereka miliki. Menemukan sendiri atau memecahkan masalah yang mereka hadapi akan menuntut siswa untuk mengembangkan cara berpikir kreatif.

Discovery learning adalah suatu tipe penularan induktif karena siswa bergerak dari mempelajari contoh-contoh spesifik sampai merumuskan aturanaturan, konsep-konsep, dan prinsip-prinsip umumnya (Schunk, 2012). Bruner menyebutkan bahwa siswa mengkostruksi pengetahuan melalui tiga cara, yaitu: 1) enactive (melakukan, dunia nyata), 2) iconic (citra dan gambar), dan symbolic (kata-kata dan simbol) (Bruner, 2018; Takaya, 2015; Wen, 2018).

Penelitian ini mengungkap bagaimana komponen berpikir kreatif siswa dalam pembelajaran matematika, dengan menggunakan langkah-langkah pembelajaran discovery learning Bruner untuk mengeksplorasi kemampuan berpikir kreatif siswa. 


\section{PEMBAHASAN}

\section{Berpikir Kreatif}

Secara umum, berpikir kreatif didefinisikan sebagai "keterampilan kognitif dalam mengajukan solusi untuk suatu masalah atau membuat sesuatu yang berguna atau ada kebaruan dari yang biasa" (Aizikovitsh-Udi \& Amit, 2011). Kreativitas matematika dalam pemecahan masalah adalah kemampuan untuk merumuskan tujuan matematika dan menemukan hubungan; kapasitas untuk memecahkan masalah sesuai dengan kelayakan mengintegrasikan sifat-deduksi logika dalam pendidikan matematika dan konsep-konsep yang berkembang ke dalam intinya. Menurut Silver dalam (Aizikovitsh-Udi \& Amit, 2011) kreativitas matematika memiliki dua karakteristik, umum dan spesifik. Pemikiran orisinal atau kreatif tertentu menghasilkan kreativitas dalam bidang tertentu. Realisasi potensi kreativitas ini membutuhkan periode pematangan dan pengembangan yang lebih lama. Perkembangan dan kedewasaan adalah hasil dari pengalaman dan biasanya menampakkan diri pada orang dewasa. Kreativitas matematika berhubungan dengan kemampuan siswa untuk memecahkan masalah rutin dan non-rutin dan bahkan yang tidak terstruktur.

Berpikir kreatif dianggap kemampuan untuk menghasilkan ide atau jawaban asli (Duff, Kurczek, Rubin, Cohen, \& Tranel, 2013) dan untuk memahami hubungan baru dan tidak terduga atau faktor yang tidak terkait (Piawa, 2010). Dalam kreativitas, kemampuan menemukan cara-cara baru dalam memandang korelasi atau solusi yang tidak biasa merupakan aspek yang sangat penting karena sangat mungkin akan menghasilkan beragam variasi solusi. Orang kreatif peka terhadap keberadaan masalah dan bahwa individu memiliki sedikit peluang untuk menunjukkan sifat-sifat kreatif tanpa adanya masalah untuk dipecahkan. Meskipun kreativitas sangat membantu untuk menyelesaikan masalah, kreativitas juga memiliki tujuan lain. Mengenali, menemukan, dan menyadari masalah adalah sifat kreativitas yang dominan.

Dalam matematika berpikir kreatif mencakup kemampuan untuk merumuskan tujuan matematika dan menemukan hubungan bawaan mereka. Runco dalam (Hadar \& Tirosh, 2019) mengaitkannya dengan berpikir divergen dan konvergen, penemuan masalah, penyelesaian masalah, melihat hubungan baru, dan membuat hubungan antara teknik, ide dan bidang aplikasi. Silver dalam (Hadar \& Tirosh, 2019) mengkarakterisasi berpikir kreatif dengan fleksibilitas mental, rasa ingin tahu, imajinasi yang berkembang dengan baik, 
minat dalam menemukan solusi, penciptaan metafora, dan pemikiran yang berorientasi pada tujuan. Berpikir konvergen, ditandai dengan menentukan pola dan memutuskan dari pola pikir yang mapan, dan pemikiran divergen, ditandai dengan merumuskan hipotesis matematika, mengevaluasi ide-ide matematika yang tidak biasa, merasakan apa yang hilang dari suatu masalah, dan memecah masalah umum menjadi subproblem tertentu. Berpikir kreatif dalam matematika membutuhkan pembentukan hipotesis, membuktikan dan meyakinkan, membangun argumen, dan membenarkan ide-ide matematika. Beberapa peneliti telah menerapkan konsep kelancaran, fleksibilitas, dan orisinalitas pada berpikir kreatif matematika.

Selain konsep kelancaran, fleksibilitas, dan orisinalitas pada berpikir kreatif matematika, proses berpikir kreatif dalam matematika juga diklasifikasikan ke dalam tiga dimensi umum, yaitu 1) berpikir lateral dalam matematika yaitu menciptakan dan mengeksplorasi cara inovatif asosiatif untuk memecahkan masalah dan menyarankan pemahaman matematika baru daripada mengikuti pola yang sudah ada sebelumnya (Hadar \& Tirosh, 2019), 2) berpikir divergen dalam matematika yaitu berpikir berbagai cara untuk menyelesaikan masalah dan menerapkan ide-ide matematika dalam konteks yang berbeda dan dalam berbagai cara (Owen-Wilson, 2016), 3) berpikir konvergen-integratif dalam matematika yaitu pengintegrasian gagasan untuk menentukan pola atau struktur matematika, menghubungkan gagasan matematika dengan bidang lain sebagai dasar untuk pemahaman matematika baru, dan menghubungkan gagasan matematika dengan konteks yang lebih luas (Aizikovitsh-Udi \& Star, 2011).

Berpikir lateral adalah cara memecahkan masalah menggunakan pendekatan tidak langsung dan kreatif melalui penalaran yang tidak segera jelas. Ini melibatkan ide-ide yang mungkin tidak dapat diperoleh hanya menggunakan logika langkah-demi-langkah tradisional. Istilah ini diumumkan pada tahun 1967 oleh Edward de Bono. Menurut de Bono (Hadar \& Tirosh, 2019) berpikir lateral sengaja menjauhkan diri dari persepsi standar kreativitas sebagai logika "vertikal", metode klasik untuk pemecahan masalah.

Berpikir divergen adalah proses pemikiran atau metode yang digunakan untuk menghasilkan ide-ide kreatif dengan mengeksplorasi banyak solusi yang mungkin (Guilford, 1967). Berpikir divergen biasanya terjadi secara spontan, mengalir bebas, "non-linear", sehingga banyak ide dihasilkan dengan cara kognitif yang muncul. Banyak solusi yang mungkin dieksplorasi dalam waktu singkat, dan koneksi yang tidak terduga dibuat. Creative Education Foundation (CEF, 2018) membuat pedoman untuk mengembangkan berpikir divergen 
antara lain: 1) tunda membuat penilaian: menunda penilaian tidak sama dengan tidak memiliki penilaian dan hindari menilai ide baik atau buruk dalam fase berpikir divergen, 2) kombinasikan dan membangun: gunakan satu ide sebagai batu loncatan untuk yang lain, bangun, gabungkan, dan tingkatkan ide, 3) cari ide liar: peregangan untuk menciptakan ide-ide liar, mendapatkan jalan lain memungkinkan ruang untuk menemukan ide-ide luar biasa, dan 4) memilih kuantitas: luangkan waktu yang diperlukan dan gunakan alat-alat dalam panduan ini untuk menghasilkan daftar panjang opsi potensial.

Deskripsi berpikir konvergen-integratif adalah mengidentifikasi elemenelemen kunci dari suatu masalah, mencari tahu bagaimana potongan-potongan tersebut bersatu. Berpikir konvergen-integratif juga mampu melihat hubungan baru, menggabungkan ide-ide yang berbeda, menentukan pola, dan membentuk hubungan baru antara entitas yang sebelumnya berbeda (Sill, 1996).

Berpikir kreatif adalah komponen penting dari pemikiran matematika tingkat lanjut, karena ia mempromosikan strategi inovatif. Berpikir kreatif melampaui matematika; itu juga berlaku untuk kemampuan untuk menangani masalah yang kompleks dan perubahan keadaan secara lebih umum. Mendorong berpikir kreatif sangat penting jika anak ingin mengembangkan pemahaman konseptual yang mendalam tentang matematika (Hadar \& Tirosh, 2019; Sheffield, 2013), tetapi berpikir kreatif sulit untuk dikembangkan. Guru tidak dapat secara langsung mengajar siswa untuk menciptakan solusi baru dan unik. Namun, mereka dapat menciptakan situasi di mana siswa berpikir kreatif (Švecová, Rumanová, \& Pavlovilová, 2014). Berpikir kreatif membutuhkan rangsangan (Ulfah, Prabawanto, \& Jupri, 2017), kegiatan yang dipilih dengan baik di mana siswa terlibat saat mereka belajar, yang membutuhkan pemikiran untuk menjauh dari ide-ide yang telah ditetapkan sebelumnya dan menghasilkan yang tidak biasa gagasan (asli). Dukungan yang mungkin untuk guru dalam proses ini adalah dengan memasukkan kegiatan berpikir kreatif dalam bahan kurikulum. Pilihan guru tentang materi kurikulum tertentu dapat memengaruhi apa yang siswa pelajari, bagaimana mereka belajar, dan tingkat kognitif di mana mereka belajar. Untuk mendorong berpikir kreatif, guru perlu menyadari jenis bahan, kegiatan/tugas yang mendukung berpikir kreatif.

\section{Discovery Learning Bruner}

Menurut Jerome S. Bruner (Bruner, 1999) discovery learning adalah metode pembelajaran yang mendorong siswa untuk bertanya dan menarik kesimpulan 
dari prinsip-prinsip umum dari contoh pengalaman praktis. Apa yang menjadi dasar dari ide Bruner adalah pernyataan dari Piaget yang menyatakan bahwa anak-anak harus belajar aktif dalam belajar di kelas. Discovery learning adalah model pembelajaran, di mana siswa membangun pengetahuan mereka sendiri dengan melakukan eksperimen untuk menemukan prinsip dari eksperimen tersebut (Saab, Joolingen, \& Hout-Wolters, 2005). Bruner mengatakan bahwa model penemuan pembelajaran adalah model di mana siswa diizinkan untuk menemukan aturan baru dan ide-ide baru, tidak menghafal apa yang dikatakan atau disampaikan oleh guru (Bruner, 2018; Mayer, 2004). Bagi Bruner, pikiran dalam beberapa bentuk operasi ada sejak awal, dan tugas yang lebih penting bagi psikologi adalah menganalisis 'kondisi yang menghasilkan pikiran manusia yang lebih kaya, lebih kuat, dan lebih percaya diri (Takaya, 2015). Inti dari penelitian Bruner menemukan objektivisme yang berlebihan, reduksionisme, sebabsebab langsung, dan determinisme dalam penelitian psikologi kontemporer, dan mencoba mengembalikan konsepsi yang lebih kaya tentang apa artinya menjadi manusia (Takaya, 2015). Untuk memahami tanda-tanda khas teori perkembangan kognitif Bruner, beberapa konsep dan topik utamanya yakni: (1) gagasan tiga mode representasi, (2) penguasaan bahasa, (3) konsep-konsep yang ia sukai setelah 'pergantian budaya,' dan (4) konstruktivisme (Takaya, 2015).

Agak mirip dengan ide Jean Piaget tentang tahap perkembangan, Bruner mengatakan bahwa ada tiga mode khas representasi yaitu enactive, iconic, dan symbolic. Siswa memperoleh mode ini satu per satu, dalam urutan enactive ke iconic dan ke symbolic, sampai akhirnya mereka menjadi mampu dari ketiga mode pemahaman. Siswa yang belum menguasai bahasa ibu mereka akan memahami dan berkomunikasi melalui perilaku; kemudian, mereka mulai menggunakan gambar konkret; dan akhirnya mereka mulai menggunakan simbol dan sekarang dapat terlibat dalam pemikiran abstrak tanpa harus bergantung pada objek atau gambar konkret (Zhou \& Brown, 2017). Mode representasi memiliki implikasi pendidikan seperti teori pengembangan tahap Piaget. Dalam mengajar anakanak kecil, guru harus dengan cermat mengamati mode mana yang dominan pada anak yang mereka ajar. Dengan mengetahui sifat dari mode representasi dan mode dominan masing-masing anak akan memungkinkan guru untuk secara efektif menyampaikan apa yang harus mereka ajarkan. Mode representasi Bruner, bagaimanapun, tidak sama dengan tahap perkembangan Piaget, karena Piaget melihat perkembangan kognitif sebagai spontan, yaitu, sebagai akibat dari pematangan internal atau fisiologis, Bruner melihatnya "sebagai konsekuensi dari pembelajaran untuk berurusan dengan dunia dalam bentuk 
bentuk budaya yang semakin maju dan mode representasi budaya”.

Tahap Enactive, yaitu tahap pembelajaran sesuatu pengetahuan di mana pengetahuan itu dipelajari secara aktif, dengan menggunakan bendabenda konkrit atau menggunakan situasi nyata (real/contextual). Tahap Iconic, yaitu tahap pembelajaran suatu pengetahuan di mana pengetahuan itu dipresentasikan (diwujudkan) dalam bentuk bayangan visual (visual imagery), gambar, atau diagram, yang menggambarkan kegiatan kongkrit yang terdapat pada tahap enactive. Tahap Symbolic, yaitu suatu tahap pembelajarn di mana pengetahuan itu dipresentasikan dalam bentuk simbol-simbol abstrak (abstract symbolic, yaitu simbol-simbol arbiter yang dipakai berdasarkan kesepakatan orang-orang dalam bidang yang bersangkutan), baik simbol-simbol verbal misalnya huruf-huruf, kata-kata, kalimat-kalimat, lambang-lambang matematika, maupun lambang-lambang abstrak lainnya.

Melalui tahap enactive, siswa bisa melakukan interaksi langsung dengan dunia nyata dengan melakukan aktivitas secara bebas. Kebebasan beraktivitas bisa memfasilitasi siswa untuk berkreasi bebas sehingga menumbuhkan kemampuan berpikir kreatif siswa. Tahap iconic, siswa dituntut untuk merepresentasikan proses enactive ke dalam gambar atau bentuk yang lain. Dengan kebebasan yang diberikan, siswa diharapkan akan menghasilkan bentuk visual yang khas sesuai dengan kreasi masing-masing siswa. Tahap terakhir adalah symbolic, meskipun ada kesamaan representasi hubungan antar simbol yang akan dihasilkan, namun siswa bisa menentukan simbol yang dikehendaki sehingga simbol yang dipilih akan lebih bermakna bagi siswa.

Menurut Bruner (Aisyah, 2007), asumsi yang mendasari discovery lerarning adalah:

1. Perolehan pengetahuan merupakan suatu proses interaktif, artinya pengetahuan akan diperoleh orang yang belajar (pebelajar) bila di dalam pembelajaran yang bersangkutan berinteraksi secara aktif dengan lingkungannya.

2. Orang yang mengkonstruksi pengetahuannya dengan cara menghubungkan informasi yang tersimpan yang telah diperoleh sebelumnya.

Bruner (Bruner, 2018) mengemukakan tiga prinsip dalam discovery learning, yaitu: 1) pengajaran harus memperhatikan pengalaman dan konteks yang membuat siswa mau dan mampu belajar (kesiapan), 2) instruksi harus terstruktur sehingga dapat dengan mudah dipahami oleh siswa (organisasi spiral), dan instruksi harus dirancang untuk memfasilitasi ekstrapolasi dan atau 
mengisi kekosongan (melampaui informasi yang diberikan).

Bruner (Wen, 2018) menjelaskan tentang discovery learning dimungkinkan melalui konsep kurikulum spiral yang melibatkan informasi yang terstruktur sehingga ide-ide kompleks dapat diajarkan pada tingkat yang disederhanakan terlebih dahulu, dan kemudian dikunjungi kembali pada tingkat yang lebih kompleks di kemudian hari. Idealnya mengajar jalannya harus mengarah pada anak-anak mampu menyelesaikan masalah sendiri. Menurut (Bruner, 2018) dalam belajar matematika menekankan pendekatan dengan bentuk spiral. Pendekatan spiral dalam belajar mengajar matematika adalah menanamkan konsep dan dimulai dengan benda kongkrit secara intuitif, kemudian pada tahap-tahap yang lebih tinggi (sesuai dengan kemampuan siswa) konsep ini diajarkan dalam bentuk yang abstrak dengan menggunakan notasi yang lebih umum dipakai dalam matematika. Penggunaan konsep Bruner dimulai dari cara intuitif keanalisis dari eksplorasi kepenguasaan. Misalnya, himpunan tiga buah mangga. Untuk menanamkan pengertian 3 diberikan 3 contoh himpunan mangga. Tiga mangga sama dengan 3 mangga.

\section{Pembelajaran Discovery Learning Bruner untuk Mengeksplorasi Kemampuan Berpikir Kreatif Siswa}

Dalam bagian ini, akan dibahas tentang contoh pembelajaran discovery learning Bruner pada pelajaran matematika untuk mengeksplorasi kemampuan berpikir kreatif siswa yang meliputi berpikir lateral, berpikir divergen, dan berpikir konvergen integratif. Contoh pembelajaran meliputi serangkaian tugas/pertanyaan dalam setiap tahap proses enactive, iconic, dan symbolic. Dalam setiap pertanyaan dan tugas akan diberikan jenis berpikir kreatif yang akan difasilitasi. Materi yang akan dipilih adalah sistem persamaan linier dua pengubah.

Materi Sistem Persamaan Linier Dua Variabel (SPLDV) diberikan pada siswa SMP/MTs kelas VIII dengan kompetensi dasar (Permendikbud, 2018) antara lain:

- KD (Kompetensi Dasar) 3.5 Menjelaskan sistem persamaan linier dua variabel dan penyelesaiannya yang dihubungan dengan masalah kontekstual

- Menyelesaikan masalah yang berkaitan dengan SPLDV.

Dengan uraian materi meliputi pengertian dan bentuk umum SPLDV, penyelesaian SPLDV dengan teknik substitusi, eliminasi, dan gabungan 
subtitusi-eliminasi, dan penyelesaian berkaitan dengan SPLDV.

Kegiatan pembelajaran meliputi: 1) kegiatan pendahuluan: penyampaian tujuan dan apersepsi, 2) kegiatan inti: enactive, iconic, symbolic, dan 3) kegiatan penutup: umpan balik dan penyimpulan.

1. Kegiatan Pendahuluan

Penyampaian tujuan: kegiatan penyampaian tujuan dimaksudkan agar siswa mendapatkan gambaran tentang tujuan pembelajaran. Penyampaian tujuan penting agar siswa mengetahui sejak awal apa yang akan dituju dan membuat siswa fokus pada pembelajaran yang akan dilakukan (Schunk, 2012). Penyampaian tujuan akan dilakukan dengan memberikan masalah kontekstual pada siswa, yaitu:

\section{Tujuan}

Hendry hendak membeli 1 lusin buku tulis dan 1 lusin bolpoin. Setelah bertanyatanya, Hendry mendapatkan informasi bahwa toko yang menjual buku tulis dan bolpoin yang dekat dekat tempat tinggal Hendry adalah toko A dan toko $B$ dengan informasi tambahan bahwa toko A menjual 3 buku tulis dan 4 bolpoin dengan harga Rp. 21.500 dan menjual 4 buku tulis dan 3 bolpoin dengan harga 24.000. Sedangkan toko B menjual 5 buku tulis dan 4 bolpoin dengan harga 29.800 dan menjual 3 buku dan 5 bolpoin dengan harga 23.600. Jika kamu dimintai saran Hendry, saran apa yang kamu berikan kepada Hendry dan apa alasannya?

Dengan masalah di atas, sejak awal siswa sudah bisa membayangkan bagaimana tujuan dan proses dalam pembelajaran akan berlangsung serta memperoleh gambaran manfaat materi yang diberikan. Masalah di atas akan mengarahkan siswa untuk berpikir lateral (cara baru), berpikir divergen (lebih dari 1 cara), dan berpikir konvergen integratif (menerapkan gagasan dan pola untuk memberi saran).

\Apersepsi:

Apersepsi dimaksudkan agar materi yang akan dipelajari menjadi bermakna bagi siswa. Menurut Ausubel (Schunk, 2012) belajar bermakna ketika materi baru memiliki hubungan sistematis dengan konsep yang relevan di long term memory. Dalam hal ini konsep yang relevan di long term memory adalah materi persamaan linier satu variabel dan persamaan linier dua variabel. Apersepsi diberikan dengan teknik tanya jawab dengan pertanyaan awal antara lain: 
Ani hendak mencetak dan menjilid laporan kerja proyek pelajaran matematika. Ani mencetak di fotokopi A dengan menghabiskan uang Rp. 12.600. Jika biaya jilid adalah Rp. 5.000 dan laporan kerja poyek Ani sejumlah 38 lembar, berapa biaya fotokopi per lembar?

Dari pertanyaan tersebut siswa diminta menyelesaikan dengan caranya sendiri (berpikir lateral). Masalah di atas dilanjutkan dengan beberapa pertanyaan bantuan dengan harapan siswa mendapatkan pola yang akan digunakan dalam menjawab masalah lain yang berkaitan dengan masalah di atas (berpikir konvergen integratif) dengan pertanyaan tambahan

Jika di tempat yang sama Adi mencetak dan menjilid laporan dengan biaya 13.800, berapa lembar laporan kerja Adi?

Selanjutnya diajukan pertanyaan tentang persamaan linier dua variabel yaitu

Ibu membeli $2 \mathrm{~kg}$ jeruk dan $3 \mathrm{~kg}$ salak dengan harga total Rp. 70.000. Berapa harga $1 \mathrm{~kg}$ jeruk dan harga $1 \mathrm{~kg}$ salak?

Pertanyaan di atas mempunyai banyak jawaban dan menuntut siswa untuk berpikir kreatif dengan banyak cara dan jawaban yang benar (berpikir divergen). Siswa bisa menjawab dengan membuat tabel harga atau mendaftarnya. Pada tahap apersepsi, guru mengingatkan siswa tentang variabel dan pemodelan matematika saat menyelesaikan persamaan linier satu variabel.

2. Kegiatan Inti

$»$ Enactive

Dalam proses ini siswa diberikan masalah nyata (real/contekstual).

Masalah 1:

Adi membeli 3 celana dan 4 kaos di Toko Jaya dengan harga Rp. 290.000. Anton membeli 4 celana dan 5 kaos di toko yang sama dengan harga Rp. 370.000. Jika Benny mau membeli 2 celana dan 3 kaos di Toko Jaya, berapa rupiah uang yang harus dibayarkan Benny?

Dengan masalah nyata di atas, siswa diberi bantuan dengan sejumlah gambar celana dan kaos. Selanjutnya siswa, secara berkelompok atau individu, menyelidiki dengan alat peraga yang diberikan untuk 
mendapatkan jawaban dari masalah di atas. Siswa dituntut untuk memikirkan cara yang tidak rutin dan melatih kreativitasnya. Aspek berpikir kreatif yang dikembangkan dengan masalah adalah berpikir lateral yaitu menemukan cara sendiri dan tidak rutin.

$>$ Iconic

Masalah 3

1) Jumlah dua bilangan adalah 7 dan selisihnya adalah 13. Tentukan hasil kali dua bilangan tersebut

2) Dalam kandang terdapat 100 ekor kambing dan ayam. Jika jumlah kaki yang ada di kandang adalah 270, ada berapa ekor kambing dan berapa ekor ayam yang ada di kandang tersebut?

3) Harga 2 kaos dan 4 baju adalah Rp. 550.000 dan harga 3 kaos dan 2 baju yang sama adalah Rp. 425.000. Jika Agus membeli 2 kaos dan 1 baju, berapa uang yang dibayar oleh Agus?

Proses enactive dan iconic ini mirip dengan proses matematisasi horizon dalam realistic mathematics education (RME) yaitu siswa menyelesaikan masalah dengan melalukan proses dan cara sendiri tanpa bergantung rumus dan simbol. Dalam proses iconic, siswa diminta menuliskan jawaban masalah 1 dengan bahasa dan cara masing-masing dan mempresentasikannya di depan. Guru bertugas membimbing dan mengarahkan proses presentasi dan diskusi. Dengan proses ini, siswa akan memperoleh banyak cara (berpikir divergen). Cara-cara tersebut selanjutnya dipilih beberapa cara untuk dielaborasi pada proses symbolic.

» Symbolic

Proses ini merupakan elaborasi dari hasil proses iconic. Dari hasil pekerjaan siswa, guru mengarahkan siswa untuk melakukan proses symbolic yaitu dengan melakukan pemodelan matematika yaitu memilih variabel untuk tiap kejadian. Setelah model matematika diperoleh, guru memilih satu pekerjaan siswa untuk dilakukan elaborasi menghasilkan metode substitusi, dan satu pekerjaan siswa untuk dilakukan elaborasi menghasilkan metode eliminasi. Selanjutnya siswa diberi masalah, 


$$
\begin{aligned}
& \text { Masalah 2: } \\
& \text { Selesaikan } \\
& \text { 1) } 2 x+3 y=7 \\
& x-y=1 \\
& \text { 2) } 2 x-y=7 \\
& x+2 y=8
\end{aligned}
$$

Siswa menggunakan pola yang diperoleh untuk menyelesaikan masalah 2 (berpikir konvergen integratif) dengan cara subtitusi dan eliminasi (berpikir divergen) dan menemukan metode baru yaitu eliminasi-substitusi (berpikir lateral). Selanjutnya guru memberi penjelasan (penguatan) tentang sistem persamaan linier dua variabel dan penyelesaiannya. Selanjutnya guru memberi masalah 3 yang bertujuan untuk melatih aspek berpikir konvergen integratif siswa

Setelah siswa mengerjakan masalah 3, siswa melakukan presentasi dan dibahas bersama-sama dengan guru. Selanjutnya siswa diminta mengerjakan soal pada tujuan di awal pembelajaran.

\section{Kegiatan Penutup}

Kegiatan terakhir adalah kegiatan penutup yaitu guru memberikan umpan balik dengan cara tanya jawab dan dilanjutkan membuat kesimpulan bersama.

\section{Simpulan}

Tahap discovery learning Bruner yaitu tahap enactive, iconic, dan symbolic. Kegiatan pembelajaran dengan discovery learning Bruner pada materi sistem persamaan linier dua variabel (SPLDV) untuk mengeksplorasi berpikir kreatif siswa adalah: 1) kegiatan pendahuluan: tujuan dan apersepsi, 2) kegiatan inti meliputi: tahap enactive, yaitu pemberian masalah contextual untuk diselesaikan dengan cara siswa sendiri untuk mengeksplorasi berpikir lateral, tahap iconic, yaitu menuliskan solusi dan presentasi untuk mengeksplorasi berpikir divergen, dan tahap symbolic, yaitu elaborasi hasil tahap sebelumnya untuk dibawa ke proses matematika berupa pemodelan dan metode eliminasi dan substitusi untuk mengeksplorasi berpikir lateral, berpikir divergen, dan berpikir konvergen integratif, dan 3) kegiatan penutup: umpan balik dan penyimpulan. 


\section{Daftar Pustaka}

Aisyah, N. (2007). Pengembangan Pembelajaran Matematika SD. Jakarta: Dirjen Dikti Depdiknas.

Aizikovitsh-Udi, E., \& Amit, M. (2011). Developing the Skills of Critical and Creative Thinking by Probability Teaching. Procedia - Social and Behavioral Sciences, 15, 1087-1091.

Aizikovitsh-Udi, E., \& Star, J. (2011). The Skill of Asking Good Questions in Mathematics Teaching. Procedia - Social and Behavioral Sciences, 15, 13541358.

Bruner, J. S. (1999). The Process of Education - A Landmark in Educational Theory. Cambridge, London: Harvard University Press, 25, 1-97.

Bruner, J. S. (2018). Jerome Bruner and Constructivism. Learning Theories for Early Years Practice.

CEF. (2018). Divergent Thinking. Retrieved from http://www. creativeeducationfoundation.org/creative-problem-solving/divergentthinking/

Dewi, S. S. K., \& Aman, A. (2019). The implementation of authentic assessment in history learning at senior high school. Journal of Social Studies (JSS), 15(2), 85-102.

Duff, M. C., Kurczek, J., Rubin, R., Cohen, N. J., \& Tranel, D. (2013). Hippocampal Amnesia Disrupts Creative Thinking. Hippocampus, 23(12), 1143-1149.

Guilford, J. P. (1967). The Nature of Human Intelligence. New York: McGraw-Hill.

Hadar, L. L., \& Tirosh, M. (2019). Creative Thinking in Mathematics Curriculum: An Analytic Framework. Thinking Skills and Creativity, 33, 100585 .

Hendriana, H., Rohaeti, E. E., \& Sumarmo, U. (2017). Hard Skill dan Soft Skill Matematik Siswa. Bandung: Refika Aditama.

Mayer, R. E. (2004). Should There Be a Three-Strikes Rule Against Pure Discovery Learning? American Psychologist, 59(1), 14-19.

McGregor, D. (2007). Developing Thinking Developing Learning. British Journal of Educational Studies.

NEA. (2012). An Educators Guide to The "Fours C's". USA.

Owen-Wilson, L. (2016). The Second Principle. Retrieved from http:// 
thesecondprinciple.com/creativity/creativity-essentials/types-of-creativethinking/

Permendikbud, N. 37. (2018). Kompetensi Inti dan Kompetensi Dasar Pelajaran pada Kurikulum 2013 pada Pendidikan Dasar dan Pendidikan Menengah. Jakarta: Kemendikbud.

Permendikbud, N. 65. (2013). Standar Proses Pendidikan Dasar dan Menengah. Jakarta: Kementerian Pendidikan dan Kebudayaan.

Piawa, C. Y. (2010). Building a Test to Assess Creative and Critical Thinking Simultaneously. Procedia-Socialand Behavioral Sciences, 2(2), 551-559.

Putri, C. A., Munzir, S., \& Abidin, Z. (2019). Kemampuan Berpikir Kreatif Matematis Siswa melalui Model Pembelajaran Brain-Based Learning. Jurnal Didaktik Matematika, 6(1), 13-28.

Rahayu, E. L., Akbar, P., \& Afrilianto, M. (2018). Pengaruh Metode Mind Mapping Terhadap Strategi Thinking Aloud Pair Problem Solving Terhadap Kemampuan Berpikir Kreatif Matematis. Journal on Education, 1(2), 271-278.

Robinson, J. R. (2011). Webster's Dictionary Definition of Creativity. Journal for Workforce Education and Development, 3(2), 34-47.

Saab, N., Joolingen, W. R., \& Hout-Wolters, B. H. A. M. (2005). Communication in Collaborative Discovery Learning. British Journal of Educational Psychology, 75(4), 603-621.

Schunk, D. H. (2012). Learning Theories An Educational Perspective. New York: Pearson.

Sheffield, L. J. (2013). Creativity and School Mathematics: Some Modest Observations. ZDM Mathematics Education, 45, 325-332.

Sill, D. J. (1996). Integrative Thinking. Synthesis, and Creativity in Interdisciplinary Studies. The Journal of General Education, 45(2), 129-151.

Singh, B. (2019). Character education in the 21st century. Journal of Social Studies (JSS), 15(1).1-12. doi: 10.21831/jss.v15i1.25226.

Siswono, T. Y. E., Rosyidi, A. H., Astuti, Y. P., \& Kurniasari, I. (2012). Pemberdayaan Guru dalam Pembelajaran Matematika untuk Meningkatkan Kemampuan Berpikir Kreatif Siswa Sd. Jurnal Ilmu Pendidikan, 18(2), 210-219.

Švecová, V., Rumanová, L., \& Pavlovičová, G. (2014). Support of Pupil 's Creative Thinking in Mathematical Education. Procedia - Social and 
Behavioral Sciences, 116, 1715-1719.

Takaya, K. (2015). Bruner's Theory of Cognitive Development. International Encyclopedia of the Social E Behavioral Sciences: Second Edition, 2, 880-885.

Ulfah, U., Prabawanto, S., \& Jupri, A. (2017). Students' Mathematical Creative Thinking Through Problem Posing Learning. Journal of Physics Conference Series, 895(1), 1-7.

Wen, P. (2018). Application of Bruner's Learning Theory in Mathematics Studies. 283(Cesses), 234-237.

Zhou, M., \& Brown, D. (2017). Educational Learning Theories: 2nd Edition. In Education Open Textbooks. Retrieved from https://oer.galileo.usg.edu/ education-textbooks/1 
Humanika, Kajian IImiah Mata Kuliah Umum, Vol. 20. No. 1. (2020), 13-30 